\title{
PEMODELAN AGENT PERANG PADA SIMULASI BATTLEFIELD MANAGEMENT SYSTEM
}

\author{
Ketut Abimanyu Munastha \\ Program Studi Teknik Elektro \\ Universitas Sangga Buana YPKP Bandung \\ ketut.abimanyu@gmail.com
}

\begin{abstract}
Abstrak
Battlefield Management System (BMS) merupakan sistem dapat memenuhi kebutuhan decisionmaking, simulasi perang, analisis, prediksi, pelatihan taktik dan strategi. Dalam sebuah simulasi BMS, terdapat unit-unit militer yang masing-masing memiliki fungsi, tugas, kemampuan dan karakteristik yang berbeda. Oleh karena itu diperlukan adanya model agen dari unit-unit militer yang merepresentasikan bentuk aset-aset pertempuran. hal ini jelas diperlukan karena pemodelan merupakan salah satu kontribusi penting bagi berjalannya simulasi pertempuran tersebut.

Pemodelan yang dilakukan menyangkut 3 jenis unit utama aangkatan darat yaitu infantri, kavaleri, dan senjata lawan tank $(S L T)$. Pemodelan agen tersebut meliputi pemodelan kecepatan gerak $\left(v_{s}\right)$ jarak pandang $(J)$, jarak tembak $\left(J_{t}\right)$, dan besar kerusakan $(S)$ dari tiap agen ke agen lainnya. Berdasarkan data unit sebenarnya dan berdasarkan pada hasil penskalaan dari peta yang digunakan pada simulasi

Hasil dari pemodelan kemudian diuji melalui program simulasi BMS yang telah dibangun sebelumnya. Pengujian yang dilakukan meliputi perbandingan dari pemodelan yang dilakukan dengan hasil dari implementasi pemodelan pada simulasi. Dari pengujian tersebut memperlihatkan bahwa hasil pemodelan yang dilakukan memiliki nilai 50\% dari model sebenarnya.
\end{abstract}

Kata Kunci: BMS, agent, Simulasi, jarak, kerusakan

\section{Pendahuluan}

Kemajuan yang sangat pesat dalam bidang teknologi sangat mempengaruhi sebuah sistem 9 pada dunia kemiliteran yang kesemuanya itu bertujuan untuk mencapai keunggulan informasi (intelijen) serta keunggulan manajemen pertempuran untuk meningkatkan keunggulan daya tempur di dalam sebuah peperangan $^{[1]}$.

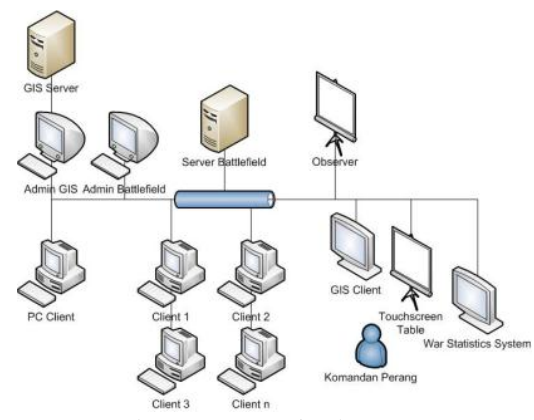

Gambar 1 : Arsitektur BMS
Battlefield Management System (BMS) adalah sebuah sistem informasi berbasis komputer yang dikembangkan untuk memenuhi kebutuhan decison-making, simulasi perang, analisis, prediksi, pelatihan taktik dan strategi. ${ }^{[3]}$

\section{Teori Penunjang}

Dalam sebuah BMS yang berbetuk simulasi pertempuran, diperlukan adanya model yang memetakan bentuk aset - aset pertempuran. hal ini jelas diperlukan karena pemodelan merupakan salah satu kontribusi penting bagi berjalannya simulasi pertempuran tersebut

Model yang akan dirancang hendaknya disesuaikan dengan kondisi aslinya, artiny dalam pembuatan model, tertama model perang harus memeperhatikan keseluhan aspek yang terdapat pada kenyataan, sehingga simulasi dapat berjalan seperti kenyataan. 


\subsection{Konsep Agent}

Saat ini banyak sekali digunakan kosa kata agent dala bidang informatika dan ilmu computer, seperti software engineering, artificial engineering, distributed system, dan sebagainya. Penggunaan teknologi agent oleh para peneliti dari berbagai bidang ilmu membuat agent didefinisikan berdasarkan latar belakang ilmu mereka sehingga sampai saat ini tidak ada definisi formal mengenai apa yang disebut agent. ${ }^{[4]}$

Dari definisi tersebut ada dua poin yang menjadi karakteristik agent, yaitu :

1. agent mempunyai kemampuan untuk melakukan suatu tugas/pekerjaan

2. agent melakukan suatu tugas / pekerjaan dalam kapasitas untuk sesuatu, atau untuk orang lain.

\subsection{Pemodelan}

Pemodelan adalah proses pengidentifikasian pengaruh dinamik fisik (sistem nyata) untuk digunakan dalam menganalisis sistem, penulisan persamaan dari hukum- hukum fisik yang relevan dan perepresentasian dalam persamaan diferensial. ${ }^{[2]}$

\subsection{Simulasi}

Simulasi adalah proses peniruan tingkah laku dari sistem yang dianalisis yang memungkinkan terjadinya perubahan perilaku dinamis melalui proses perubahan parameterparameter yang dinyatakan dalam model tersebut. $^{[2]}$

\subsection{Heuristik dan Stokastik}

Terdapat metode yang digunakan untuk melakukan pengategorian dari simulasi militer menjadi dua area, yaitu:

1. simulasi heuristic, merupakan simulasi yang bersumber lebih memperhatikan stimulasi penelitian dan pemecahan masalah. Simulasi ini tidak terlalu mementingkan untuk menghasilkan solusi empiris. Pada simulasi heuristic selalu mengeksplorasi suatu skenario "what if" dan menempati sebanyak mungkin partisipan dengan suatu perhatian terhadap proses pengambilan keputusan dan manajemen krisis untuk menghasilkan kesimpulan.

2. simulasi stokastik, merupakan simulasi yang melibatkan setidaknya terdapat perluasan. Simulasi ini dapat dikategorikan sebagai computerized simulation yang artinya tidak dilakukan secara manual, akan tetapi dengan bantuan komputer. Simulasi secara komputerisasi ini dapat siap dimasukan banyak cara ataupun metode dari sebuah elemen acak, dan bisa mengeksekusinya sebanyak yang diinginkan untuk menghasilkan sebuah keluaran. Pada situasi tertentu, dapat terjadi hasil yang tidak biasa ditemukan sehingga beberapa model dapat dihasilkan. Analisis dengan simulasi stokastik ini kemudian digunakan sebagai suatu rekomendasi.

\section{Perancangan Agent}

Pada penelitian ini akan membahas perancangan NPC pada simulasi perang khususnya angkatan darat menggunakan metode stokastic . Unit-unit tersebut meliputi infantri, SLT dan kavaleri.

Ada beberapa ketentuan umum yang digunakan untuk membuat model agent perang antara lain.

1. Health point dari tiap unit sebesar $100 \%$.

2. Akurasi dari tiap unit sebesar $90 \%$ (digunakan persentase $10 \%$ sebagai faktor eksternal).

3. Pelindung pada unit kavaleri sebesar $25 \%$ dari jumlah health point.

4. Pelindung dari unit infantri sebesar $10 \%$ dari jumlah health point.

5. Kecepatan gerak unit infantri dan SLT yaitu $4 \mathrm{~km} / \mathrm{h}$.

6. Jarak pandang unit infantri dan SLT yaitu $400 \mathrm{~m}$.

7. Jarak pandang unit kavaleri sama dengan jarak tembaknya.

8. Besar serangan kavaleri disesuaikan dengan besar kaliber unit dilapangan.

9. Besar serangan area yaitu $5 \times 5$ cell.

\subsection{Perancangan Agent}

Agent kavaleri yang dirancang merupakan jenis leopard. Beberapa nilai yang ditentukan dalam perancangan antara lain :

1. health point $(\mathrm{HP})=100$

2. $\operatorname{armor}$ (pelindung) $=\mathrm{P}$

$$
P=0.25 \times H P
$$


3. $\quad$ sight $($ jarak pandang $)=\mathrm{J}$

$$
J=\frac{J t}{8 \mathrm{~m} / \mathrm{cell}}
$$

4. attack strength (besar serangan) $=\mathrm{S}$

$$
S=\frac{V}{8}+k
$$

5. attack var (faktor eksternal) $=\mathrm{E}$

$$
E=0.1 \times S
$$

6. $\quad$ speed $($ kecepatan $)=\mathrm{Vs}$

$$
v_{s}=\frac{s}{s_{c}}
$$

untuk kecepatan dimana $\mathrm{s}$ merupakan jarak tempuh sebenarnya dan $\mathrm{s}_{\mathrm{c}}$ merupakan scaling.

\subsection{Jenis Agent}

Beberapa jenis agent yang dirancang antara lain agent infantry, agent kavaleri, agent SLT

\subsubsection{Agent Infantri}

Beberapa spesifikasi dari agent yang digunakan antara lain.

1. Senjata MP5 kaliber $9 \mathrm{~mm}^{[6]}$

2. kecepatan dorong $350 \mathrm{~m} / \mathrm{s}^{[6]}$

3. Jarak efektif $100 \mathrm{~m} \cdot{ }^{[6]}$
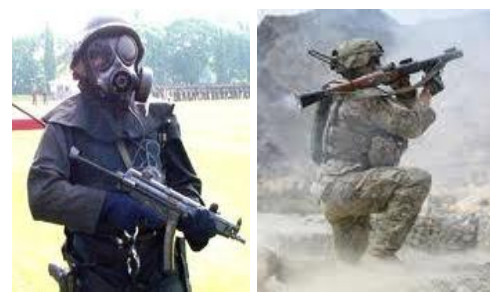

Gambar 2 : Infantri dengan senjata MP5 dan

\section{SLT}

\subsubsection{Agent Kavaleri}

Beberapa spesifikasi dari agent yang digunakan antara lain.

- Senjata utama $120 \mathrm{~mm}$ Rheinmetall L55. ${ }^{[5]}$

- Jarak tembak efektif 4000 m. ${ }^{[5]}$

- Kecepatan gerak $72 \mathrm{~km} / \mathrm{h}^{\left[{ }^{[5]}\right.}$

- Pelindung utama $3^{\text {rd }}$ generation composite. ${ }^{[5]}$

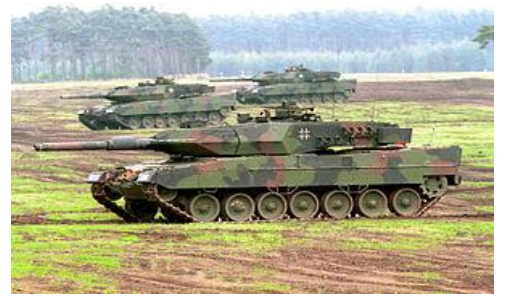

Gambar 3 : Tank Leopard 2A5

\subsubsection{Agent SLT (Senjata Lawan Tank)}

Beberapa spesifikasi dari agent yang digunakan antara lain.

1. Kaliber $40 \mathrm{~mm}^{[7]}$

2. Kecepatan dorong $115 \mathrm{~m} / \mathrm{s}^{[7]}$

3. Jarak efektif $200 \mathrm{~m} .{ }^{[7]}$

\subsection{Jarak pandang}

Terdapat 2 jenis jarak pandang yaitu jarak pandangan agen secara umum $(J)$ dan jarak pandang berdasarkan senjata $\left(J_{t}\right)$. Jarak pandang umum dari agent terutama agent infantri dan SLT adalah $400 \mathrm{~m}$. Dari jenis senjata dapat pula diperoleh jarak pandang yang dihasilkan oleh sebuh agen. jarak pandang berperan sangat penting dalam sebuah peperangan karena jika sebuah agen masuk jarak pandang agen lain yang menjadi musuh, maka akan terjadi baku tembak antar agen tersebut.hal ini berlaku pada agent kavaleri karena jarak pandangnya diperoleh secara langsung dari jenis senjata yang digunakan.

\subsection{Faktor Eksternal}

Faktor eksternal yang sering menjadi permasalahan dalam penggunaan senjata adalah arah dari proyektil yang ditembakkan, apakah bergerak lurus ke sasaran tembak atau melenceng beberapa jarak dari sasaran tembak. Ketepatan dari dari proyektil tersebut ditentukan sebesar $90 \%$ sehingga faktor ekternal yang diperoleh untuk mendapatkan besar serangan (S) yaitu $10 \%$ (sisa dari akurasi) maka dapat dihitung berapa besar faktor eksternal (E) dari sebuah serangan.

$$
E=0.1 \times S
$$

\subsection{Faktor Kelemahan}

Faktor lain yang perlu diperhatikan dalam perhitungan kerusakan adalah faktor kelemahan. Faktor kelemahan berhubungan dengan jenis seragan dan pelindung yang dimiliki oleh setiap unit. berikut merupakan jenis sreangan beserta jenis pelindung beserta nilai faktor kelemahannya.

Tabel 1 : faktor kelemahan

\begin{tabular}{|c|c|c|}
\hline Serangan/pelindung & Baja & seragam \\
\hline Peluru & 0 & 1 \\
\hline RPG & 2 & 2 \\
\hline Misil & 1 & 2 \\
\hline
\end{tabular}




\section{Implementasi Dan Pengujian}

\subsection{Implementasi Agent}

Pada bagian ini diuraikan mengenai proses implementasi sistem sesuai dengan rancangan yang sudah diuraikan di bab III. Akan diuraikan mengenai penyesuaian agent, berapa kecepatan standar pergerakan agent pada simulasi dan berap kerusakan yang dihasilkan oleh tiap agent

\subsubsection{Implementasi Penskalaan}

Konversi map dilakukan agar pada saat simulasi menggunakan map yang mendekati keadaan nyata dilapangan. Konversi dilakukan dari data GIS yang menggunakan format PNG ke data map simulasi yang menggunakan format MGM.

Untuk melakukan konversi diperlukan area yang mempunyai pixel yang sama dengan map pada simulasi, misalkan map area pada simulasi menggunakan 256x256 pixel maka area yang harus kita ambil dari GIS mempunyai ukuran sama.

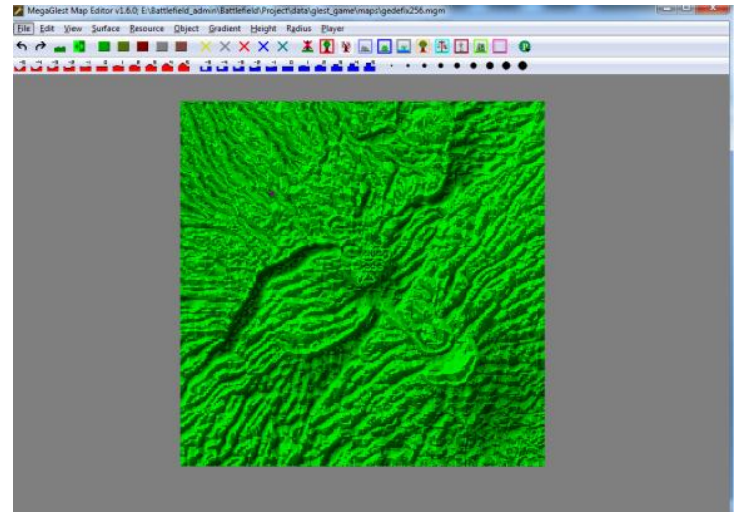

Gambar 4 : Konversi ke MGM

Digunakan scaling terlebih dahulu untuk memudahkan perhitungan dalam simulasi.

$$
s_{c}=\frac{2000 \mathrm{~m}}{256 \mathrm{cell}}=7.8125 \mathrm{~m} / \mathrm{cell} \approx 8 \mathrm{~m} / \text { cell }
$$

Nilai $8 \mathrm{~m} /$ cell merupakan skala baku yang akan digunakan sebagai perbandingan jarak dari peta nyata ke peta simulasi. Cell sendiri merupakan ukuran yang digunakan pada peta hasil konveri dengan format .mgm. satu cell pada peta konversi berdasarkan perhitungan melambangkan $8 \quad m$ ukuran pada peta sebenarnya.

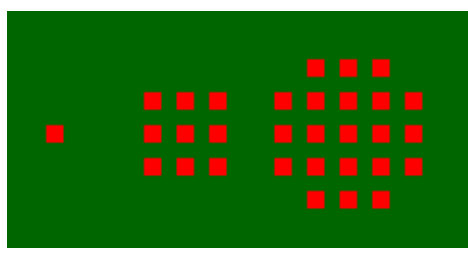

Gambar 5 : Besar cell pada peta konversi ukuran $1 \times 1,3 \times 3$, dan $5 \times 5$.

\subsubsection{Implementasi Agent}

Dengan menggunakan perumusan pada pembahasan sebelumnya di peroleh beberapa penyesuaian dari agent yang digunakan.

\subsubsection{Agent Infantri}

Spesifikasi Agent antara lain :

1. Health Point (Hp): 100

2. Armor (Pelindung) $=\mathrm{P}=10$

3. Sight (Jarak Pandang) $=\mathrm{J}=50$

4. Attack Strength (Besar Serangan) $\mathrm{S}=53$

5. Attack Var (Faktor Eksternal $)=5$

6. Attack Range $($ Jarak Tembak $)=\mathrm{Jt}=13$

7. Speed $($ Kecepatan $)=V s=250$

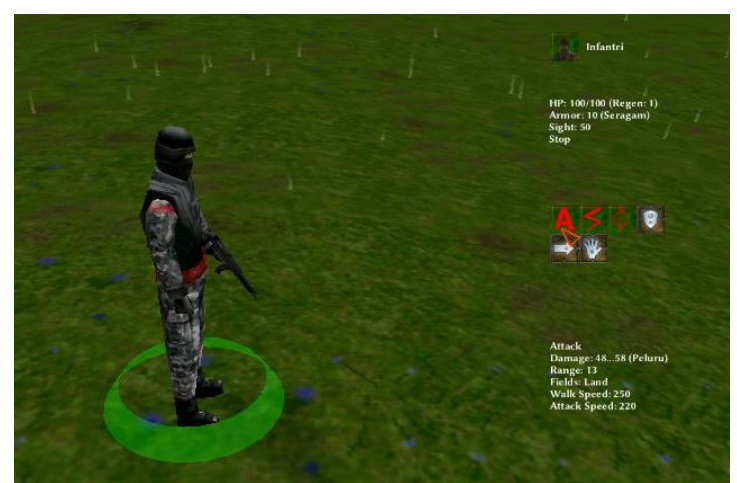

Gambar 6 : Implementasi agen Infantri

\subsubsection{Agent Kavaleri}

Spesifikasi Agent antara lain :

1. Health Point $(\mathrm{Hp}): 100$

2. Armor (Pelindung) $=\mathrm{P}=25$

3. Sight (Jarak Pandang) $=\mathrm{J}=63$

4. Attack Strength (Besar Serangan) $\mathrm{S}=120$

5. Attack Var (Faktor Eksternal $)=12$

6. Speed $($ Kecepatan $)=$ Vs $=563$ 


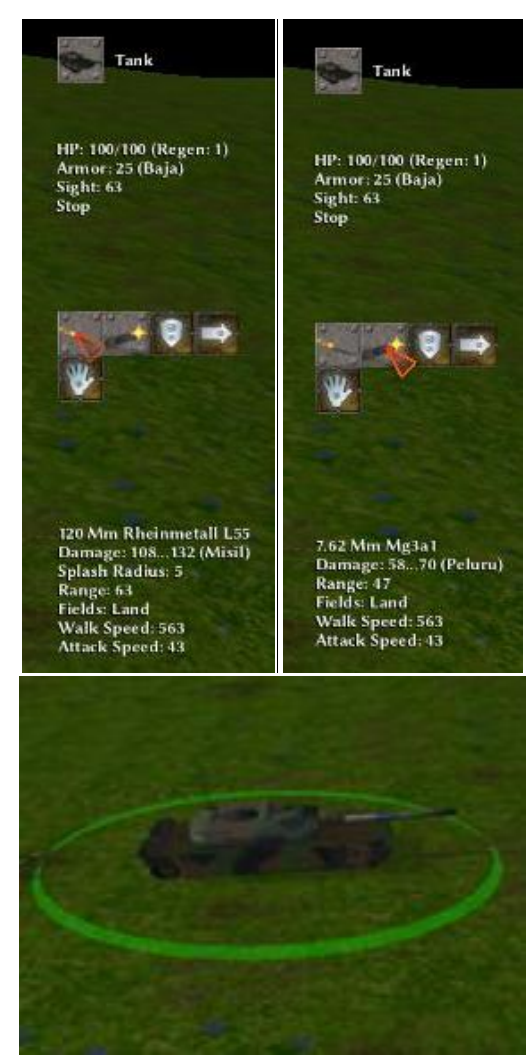

Gambar 7 : Implementasi agen Kavaleri

\subsubsection{Agent SLT}

Spesifikasi Agent antara lain :

1. Health Point $(\mathrm{Hp}): 100$

2. Armor (Pelindung) $=\mathrm{P}=10$

3. $\quad$ Sight (Jarak Pandang) $=\mathrm{J}=50$

4. Attack Strength (Besar Serangan) $\mathrm{S}=54$

5. Attack Var (Faktor Eksternal) $=5$

6. Attack Range $($ Jarak Tembak $)=\mathrm{Jt}=25$

7. Speed $($ Kecepatan $)=\mathrm{Vs}=250$

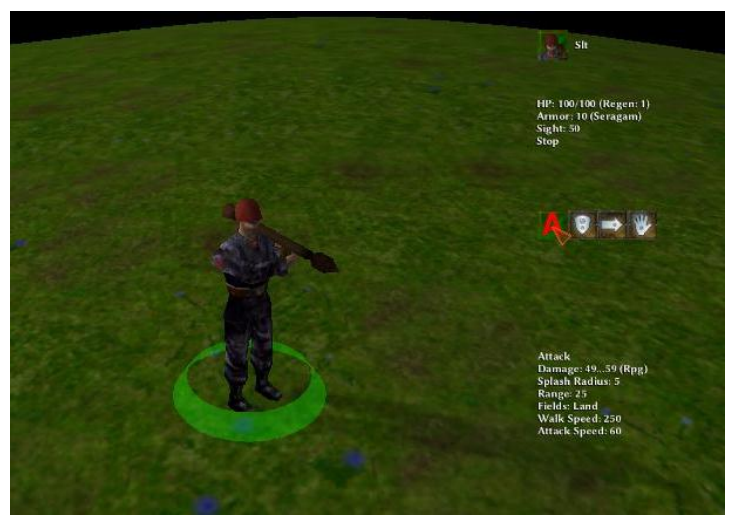

Gambar 8 : Implementasi agen SLT

\subsection{Pengujian Agent}

Pengujian yang dilakukan yaitu dengan melakukan simulasi menggunakan model yang telah diimplementasikan berdasarkan skenario yang telah ditentukan sebelumnya.

Pengujian dilakukan oleh beberapa pihak termasuk oleh pihak militer, meliputi kemampuan agen untuk berjalan, kemampuan agen untuk menghasilkan kerusakan, dan kemampuan agen untuk berhana dari serangan.

Ketiga parameter tersebut dijadikan acuan untuk memberikan penilaian apakah model tersebut dapat merepresentasikan kondisi dari unit sebenarnya.

Ada beberapa ketentuan yang digunakan dalam melakukan simulasi perang antara lain :

1. agen SLT dikhususkan untuk menembak agen kavaleri,

2. agen infantri dikhususkan untuk menembak agen SLT dan infantri,

3. agen kavaleri hanya dapat menembak agen kavaleri menggunakan senjata utama,

Pengujian pergerakan unit dilakukan dengan menggerakkan model dari salah satu ujung peta ke ujung peta lainnya, dan memperhitungkan berapa waktu yang ditempuh oleh tiap agen yang dimodelkan.

Pengujian kerusakan dilakukan dengan memerintahkan agen untuk saling menyerang dengan memperhatikan skenario yang ditentukan sebelumnya. Sedangkan pengujian ketahanan dilakukan bersamaan dengan pengujian kerusakan, yaitu berapa lama agen dapat bertahan dari serangan agen lain pada pertempuran.

\subsubsection{Kerusakan}

Faktor - faktor yang menyebabkan kerusakan antara lain $\mathrm{S}=$ besar serangan, $\mathrm{E}=$ faktor eksternal, $\mathrm{P}=$ pelindung, $\mathrm{K}=$ faktor kelemahan. Sehingga $\mathrm{D}=$ kerusakan yang dihasilkan dapat dirumuskan :

$$
D=((S \pm E)-P) \times K
$$




\subsubsection{Agent Infantri}

Kerusakan yang dihasilkan oleh agent infantri terhadap pelindung seragam pada jarak tembak efektif dapat dipetakan pada tabel berikut.

Tabel 2 : kerusakan hasil agent infantri ke agent infantry dan SLT

\begin{tabular}{|c|c|c|}
\hline $\begin{array}{c}\text { Tembakan } \\
\text { ke- }\end{array}$ & kerusakan & Sisa HP \\
\hline 1 & $\begin{array}{c}100-(((53+4)- \\
10) \times 1)\end{array}$ & 53 \\
\hline 2 & $53-(((53+3)-10) \times 1)$ & 10 \\
\hline 3 & $10-(((53-2)-10) \times 1)$ & 0 \\
\hline
\end{tabular}

\subsubsection{Agent SLT}

Kerusakan yang dihasilkan oleh agent SLT terhadap pelindung seragam pada jarak tembak efektif dapat petakan pada tabel berikut .

Tabel 3 : kerusakan hasil agent SLT ke agent infantry dan SLT

\begin{tabular}{|c|c|c|}
\hline $\begin{array}{c}\text { Tembakan } \\
\text { ke- }\end{array}$ & kerusakan & Sisa HP \\
\hline 1 & $\begin{array}{c}100-(((54-3)- \\
10) \times 2)\end{array}$ & 12 \\
\hline 2 & $12-(((54+1)-10) \times 2)$ & 0 \\
\hline
\end{tabular}

Tabel 4 : kerusakan hasil agent SLT ke agent Tank

\begin{tabular}{|c|c|c|}
\hline $\begin{array}{c}\text { Tembakan } \\
\text { ke- }\end{array}$ & kerusakan & Sisa HP \\
\hline 1 & $\begin{array}{c}100-(((54-0)- \\
25) \times 2)\end{array}$ & 42 \\
\hline 2 & $12-(((54+3)-25) \times 2)$ & 0 \\
\hline
\end{tabular}

\subsubsection{Agent Kavaleri}

Kerusakan yang dihasilkan oleh agent kavaleri terhadap pelindung baja pada jarak tembak efektif dapat dipetakan pada tabel berikut .

Tabel 5 : kerusakan hasil agent kavaleri ke agent kavaleri

\begin{tabular}{|c|c|c|}
\hline $\begin{array}{c}\text { Tembakan } \\
\text { ke- }\end{array}$ & Kerusakan & $\begin{array}{c}\text { Sisa } \\
\text { HP }\end{array}$ \\
\hline 1 & $100-(((120+5)-25) \times 1)$ & 0 \\
\hline
\end{tabular}

\section{Kesimpulan}

Terdapat beberapa hal yang dapat disimpulkan dari penelitian, antara lain ; 1. jenis agen yang dimodelkan belum merepresentasikan model unit perang sebenarnya, karena kurangnya aspek- aspek detail dari unit perang yang dimodelkan, terutama pada permasalahan proyektil senjata,

2. Keterbatasan dari peta yang digunakan berpengaruh besar pada pemodelan yang dilakukan, serta pemodelan yang dilakukan tidak bersifat adaptif karena untuk membuat model yang baru harus melakukan remodeling dari awal.

3. Dari pengujian tersebut memperlihatkan bahwa hasil pemodelan yang dilakukan memiliki nilai representasi $50 \%$ dari model sebenarnya.

\section{PUSTAKA}

[1] Irawan, Bambang S., "Strategi Perencanaan Sistem Pertahanan dan Sistem Manajemen Pertempuran", Set Balitbang Dephan

[2] Robert L. Woods, Kent L. Lawrence. "Modelling and Simulation of Dynamic Systems". Prentice Hall International. 1997.

[3] Lickteig, Carl W., "Design Guidelines and Functional Specifications for Simulation of the Battlefield Management System's (BMS) User Interface", ARI Field Agent, July, 1988.

[4] Suasnawa, I Wayan, "Desain Perilaku Agent Pada Game Strategi (Studi Kasus Game RTS Sultan Agung", ITB, 2008.

[5] Gelbart, Marsh (1996). Tanks: main battle and light tanks. Brassey's UK Ltd. pp. 109-110.

[6] "RPG-7/RPG-7V/RPG-7VR Rocket Propelled Grenade Launcher (Multi Purpose Weapon)". Defense Update. 2006. Retrieved 23 January 2011.

[7] "Pakistan Ordnance Factories". Pof.gov.pk. Retrieved 2012-12-29. 